\title{
Vascular Endothelial Growth Factor Receptor 1
}

National Cancer Institute

\section{Source}

National Cancer Institute. Vascular Endothelial Growth Factor Receptor 1. NCI Thesaurus. Code $\mathrm{C} 17975$.

Vascular endothelial growth factor receptor 1 (1338 aa, 151 kDa) is encoded by the human FLT 1 gene. This protein is involved in angiogenesis, tyrosine phosphorylation, ligand binding and signal transduction. 